\title{
Physicochemical characteristics of ozonated sunflower oils obtained by different procedures
}

\author{
By M.F. Díaz ${ }^{1, *}$, Y. Sánchez ${ }^{1}$, M. Gómez ${ }^{1}$, F. Hernández ${ }^{2}$, M.C. da C. Veloso³, \\ P.A. de P. Pereira ${ }^{3}$, A.S. Mangrich ${ }^{4}$ and J.B. de Andrade ${ }^{3}$ \\ ${ }^{1}$ Ozone Research Center, Havana, Cuba \\ ${ }^{2}$ Pharmacy and Food Institute from Havana University \\ ${ }^{3}$ Chemical Institute-Federal University of Bahia \\ ${ }^{4}$ Chemical Institute-Federal University of Parana \\ *Corresponding author: maritzafdg@infomed.sld.cu
}

\section{RESUMEN}

Características físico-químicas de aceites de girasol ozonizados obtenidos mediante diferentes procedimientos.

Se ha aplicado dos procedimientos de ozonización a aceites de girasol a diferentes dosis de ozono, obteniendo el ozono a partir de oxígeno medicinal y de aire. Se han determinado los índices de peróxido, yodo y acidez conjuntamente con la densidad, viscosidad y la actividad antimicrobiana. La composición de ácidos grasos fue analizada mediante CG. El contenido de oxígeno fue determinado mediante Análisis Elemental. Se utilizó la resonancia paramagnética electrónica para medir los radicales libres orgánicos. Las reacciones fueron realizadas hasta valores de índice de peróxidos de 658 y 675 mmol-equiv $\mathrm{kg}^{-1}$ usando oxígeno medicinal y aire durante 5 y 8 horas, respectivamente. Las muestras de aceite de girasol ozonizado no presentaron radicales libres orgánicos, lo cual es muy importante en el caso de que estos aceites sean utilizados en medicina. La reacción de ozonización es más rápida cuando se utiliza oxígeno medicinal $(5$ horas) que el aire (8 horas). El aceite de girasol ozonizado con oxígeno como fuente de ozono presentó mayor potencial de actividad antimicrobiana.

PALABRAS CLAVE: Aceite de girasol ozonizado - Actividad antimicrobiana - Análisis Elemental - Cromatografía Gaseosa - Índice de acidez - Índice de peróxidos - Indice de Yodo.

\section{SUMMARY}

Physicochemical characteristics of ozonated sunflower oils obtained by different procedures.

Two ozonation procedures for sunflower oils at different applied ozone dosages were carried out. Ozone was obtained from medicinal oxygen and from air. Peroxide, acidity, and iodine indexes, along with density, viscosity and antimicrobial activity were determined. The fatty acid compositions of the samples were analyzed using GC. The content of oxygen was determined using an elemental analysis. Electronic Paramagnetic Resonance was used to measure the organic free radicals. The reactions were achieved up to peroxide index values of 658 and $675 \mathrm{mmol}-$ equiv $\mathrm{kg}^{-1}$ using medicinal oxygen and air for 5 and 8 hours, respectively. The samples of ozonized sunflower oil did not present organic free radicals, which is a very important issue if these oils are to be used as drugs. The ozonation reaction is more rapid with medicinal oxygen (5 hours) than with air (8 hours). Ozonized sunflower oil with oxygen as an ozone source was obtained with high potential for antimicrobial activity.

KEY-WORDS: Acidity index - Antimicrobial activity Elemental Analysis - Gaseous Chromatography - lodine index - Ozonized sunflower oil - Peroxides index.

\section{INTRODUCTION}

The characterization of vegetable oils has been subjected to academic studies and commercial interest for many years. Vegetable oils show a wide variety of fatty acid composition, which is associated with the characteristics and properties of the oils (Gunstone et al., 1994). The reaction of ozone with vegetable oils occurs with the carbon-carbon double bonds present in unsaturated fatty acids. This reaction produces several products such as hydroxiperoxides, hydrogen peroxides, Criegee ozonides and aldehydes that could be responsible for the biological activity of ozonized vegetable oils (Criegee 1975, Díaz et al., 2005, Díaz et al., 2008, Díaz et al., 2011). The yield of oxygenated compounds from unsaturated oils depends on reaction conditions, such as the temperature, the applied ozone doses, the reactor, etc. (Bailey et al., 1978).

In Cuba, several procedures have been designed for the elaboration of ozonized vegetable oils (Molerio et al., 2009) presenting therapeutic and cosmetic properties. In this study, authors have developed two procedures using different sources for obtaining the ozone: air and oxygen. Given the differences between the composition of air and oxygen, the ozone obtaining procedure is much easier starting from oxygen than from air. Ozone is produced from an energy source in the oxygen gas. Since oxygen gas contains $99 \%$ pure oxygen and in air gas there is $21 \%$, it is much faster to obtain ozone from pure oxygen than from air. 
Oxygenated compounds obtained from the ozonation of vegetable oils do not contain free radicals; although they might induce the formation of these highly reactive species. For this reason, in this field, it is very important to determine the presence of free radicals once the ozonized vegetable oil has been obtained. The technique of Electron Paramagnetic Resonance (EPR) represents a powerful tool for determining the levels of free radicals in ozonized vegetable oils (Lezama, 1997).

Knowledge concerning the physical-chemical properties of ozonized vegetable oils has great importance for their identification and characterization. The determination of viscosity and density as well as volumetric methods such as peroxide, acidity and iodine indexes are relevant for the identification and quality control of these oils (NC, 1998).

The percentage of content of oxygen at different applied ozone dosages can be known by means of the technique of elemental analysis (Pasto and Johnson, 1980). Another method used in the structural characterization of ozonized vegetable oil is Gaseous Chromatography Technique for fatty acid analysis and triglycerides with a high efficiency of separation (Garcés and Mancha, 1993; Geeraert and Shepeer, 1982).

Sunflower oil, with a composition rich in linoleic $(48-74 \%)$ and oleic acids (14-39\%), acquires germicidal properties (Molerio et al., 2009) once it is ozonized. Most of the ozonized vegetable oils found in the literature are obtained using medicinal oxygen as the ozone source (Díaz et al., 2005; Díaz et al., 2007; Sechi et al., 2001). However, we have not found any article using air as the ozone source for achieving theses ozonized oils, nor an analysis that demonstrates the presence of organic free radicals.

The objective of this work is the comparison among several samples of ozonized sunflower oil at different ozone dosages employing two ozonation procedures, using either air or medicinal oxygen as the ozone source. Peroxide, acidity, and iodine indexes along with density, viscosity and antimicrobial activity are determined. The ozonation effects on the fatty acid composition of these samples are also analyzed using the Gaseous Chromatography Technique. In addition, oxygenated compound contents are determined using the technique for element analysis, and the presence of organic free radicals is detected by Electronic Paramagnetic Resonance.

\section{MATERIALS AND METHODS}

\subsection{Solvents and reagents}

Glacial acetic acid, chloroform, potassium iodine, sodium thiosulfate, starch, ethanol, ether, potassium hydroxide, phenolphthalein, iodine bromide, toluene, and dimetoxipropane were purchased from MERCK (Germany). Edible sunflower oil was obtained from Campo Grande, NIDERA SA registered trademark, Argentina.

\subsection{Ozonation procedure}

Edible sunflower oil (200 mL) was introduced into a bubbling reactor where an ozone reaction took place in a water bath, at room temperature $\left(25^{\circ} \mathrm{C}\right)$. The ozonation was allowed to continue for 5 and 8 hours employing medicinal oxygen and air as the ozone source, respectively. The applied ozone dosages (medicinal oxygen: 12, 23, 35, 47, $59 \mathrm{mg} \mathrm{g}^{-1}$, and air: 12, 23, 35, $47 \mathrm{mg} \mathrm{g}^{-1}$ ) were obtained, respectively, through different bubbling times (medicinal oxygen: 1, 2, 3, 4, 5 h; and air: 2, 4, 6, 8 h). Ozone dosages were chosen to achieve peroxide values ranging between 100 and 700 mmol-equiv $\mathrm{kg}^{-1}$ ). Five and four samples were taken in each ozonation procedure, respectively. Three replicates were carried out for each ozone dosage and the replicates were averaged. The Samples were stored at $2-8^{\circ} \mathrm{C}$ for 24 hours before analysis.

\subsection{Ozone generation}

Ozone was generated passing oxygen through a Trailigaz Labo model 12-02 ozone generator at a fixed voltage $(170 \mathrm{~V})$, and a constant flow rate of 30 $\mathrm{L} \mathrm{h}^{-1}$. The ozone initial concentration of the resulting stream (medicinal oxygen: $75 \mathrm{mg} \mathrm{L}^{-1}$ and air: $36 \mathrm{mg}$ $\mathrm{L}^{-1}$ ) were determined using Anseros Ozomat equipment.

\subsection{Analysis Techniques}

Chemical-Physical Techniques. The peroxide value was expressed as mmol-equiv of active oxygen in $1 \mathrm{~kg}$ of the sample BP. (2000a). The acid value was expressed as $\mathrm{mg}$ of $\mathrm{KOH}$ required to neutralize the free acids in $1 \mathrm{~g}$ of the substance BP. (2000b). The iodine value represented the double bonds contained in $1 \mathrm{~kg}$ of the sample BP (2000c). The density value, represented the proportion between the mass of a substance and its volume at a determined temperature $\left(\mathrm{g} \mathrm{mL}^{-1}\right) \mathrm{BP}$. (2000d) and the viscosity value was expressed as $\mathrm{m}$. The $\mathrm{Pa}$. represented the resistance of fluids to flue due to the internal friction among its molecules BP. (2000e).

Element analysis. The element analysis technique was carried out using equipment from LECO CHNS-932 Corporation ST JOSEPH MI USA. The total contents of Carbon $(C)$, hydrogen $(H)$, nitrogen (N) and sulphur (S) were measured in an oxidation oven at a temperature of $1100 \pm 1^{\circ} \mathrm{C}$ and in a reduction oven up to $950^{\circ} \mathrm{C}$ (nominal $550^{\circ} \mathrm{C}$ ). In addition, a micro analytical balance of $0,001 \mathrm{mg}$ was connected to the system. The oxygen content was determined by the difference in the $\mathrm{C}, \mathrm{H}, \mathrm{N}$, and $S$ values with respect to $100 \%$ (Pasto and Johnson, 1980).

Gaseous Chromatography (GC). The ozonation effects on the fatty acid composition of ozonized sunflower oil samples obtained by both procedures were analyzed. For the gas chromatography analysis of esterified fatty acids, methyl ester derivatives were 
first prepared by transesterification as described by Garcés et al. (1993).

A model Hewlett Packard 5890 Sequence II Chromatographic System was used for the esterified fatty acids assay. Analyses were performed in a Supelco SP-2380 capillary column $(30 \mathrm{~m} \times 0.32 \mathrm{~mm}$ $\mathrm{ID}$, film thickness $0.20 \mu \mathrm{m}$ ) with a flame ionization detector at $280^{\circ} \mathrm{C}$. The carrier gas for esterified fatty acid analysis was hydrogen at a flow rate of $1 \mathrm{~mL} / \mathrm{min}$ and a pressure of $50 \mathrm{Kpa}$. For the analysis of the fatty acids the column temperature was programmed from 100 to $200^{\circ} \mathrm{C}$ with an increase of $8^{\circ} \mathrm{C}$ per minute, using an injection volume of $2 \mu \mathrm{L}$. An external fatty acid standard (Sigma-Aldrich Chemical Company) was used to identify components.

Electronic Paramagnetic Resonance (EPR). An Electron Paramagnetic Resonance spectrometer Bruker ESP 300E EPR was used to detect the presence of free radicals in sunflower oil and ozonized sunflower oil samples with peroxide index values of 655 and 678 mmol-equiv $\mathrm{kg}^{-1}$. These spectra were registered with a modulation frequency of $100 \mathrm{kHz}$, operating at a frequency in the X-band ( 9.5 GHz), an amplitude modulation of 5 to $10 \mathrm{G}$, depending on the spectrum. Quartz tubes of $3 \mathrm{~mm}$ in diameter were used for spectra at room temperature $(300 \mathrm{~K})$, working with a magnetic field ranging from 3 325 to 3600 Gauss Lezama, (1997).

\subsection{Antimicrobial activity}

The antimicrobial activities of the ozonized sunflower oils obtained by both procedures with different peroxide values were determined in bacterial strains. Staphylococcus aureus ATCC 25923, Escherichia Coli ATCC 25922 and Pseudomonas aeruginosa ATCC 27853 were chosen. Minimum Inhibitory Concentrations (MICs) and Minimum Bactericidal Concentrations (MBCs) using agar dilution and macro dilution methods were based on the National Committee for Clinical Laboratory Standards (NCCLS, 2000 and NCCLS, 1999). The spectrum of antimicrobial activity was obtained from the samples presenting the middle and high peroxide indexe values.

\subsection{Statistical analysis}

Analyses were carried out in triplicate and were expressed as mean \pm standard deviation (SD). A linear regression analysis was performed using the Statistical software package version 6.0 Statistic, (2003).

\section{RESULTS AND DISCUSSION}

\subsection{Analysis of the Chemical-Physical Parameters}

During the ozonation reaction, peroxide, acidity index, density and viscosity values increased with applied ozone dosage, and all of these peroxide index values were used to carry out both sunflower oil ozonation procedures with oxygen and air as ozone sources. The increase in these parameters is due to the formation of oxygenated compounds during and after the ozonation reaction. This is in agreement with the results described for the Criegee mechanism for ozone reaction with olefins. Criegee, (1975).

The reactions were achieved up to peroxide index values of 658 and $675 \mathrm{mmol}-\mathrm{equi}^{-1}$ during 5 and 8 hours, respectively. In (Figure 1), it can be seen that for both ozonation methods linear correlations exist and its coefficients are superior to 99\% (equations 1 and 2) between applied ozone dosages and reaction times.

$$
\begin{aligned}
& \text { Equation } 1 \mathrm{AOD}=0,244+5.85 \mathrm{t}(r=99.98 \% \text {, } \\
& \text { Equation } 2 \quad \begin{aligned}
r^{2} & =99.97 \%)(\text { Air }) \\
\text { AOD } & =-0.095+11.77
\end{aligned} \\
& \left(r=99.99 \%, r^{2}=99.98 \%\right) \text { (Oxygen) }
\end{aligned}
$$

In Tables 1 and 2, the consumed moles of double bond for each point of the ozonation reaction can be observed. In total, 0.159 moles of double bonds were consumed in both reactions, as long as iodine index values decreased. Therefore, it can be affirmed that, while ozonation reaction progresses, the consumed double bond moles are directly proportional to the applied ozone dosage, resulting in the fact that the ozonation reaction from oxygen best adjusts to the linear model (equations 3 and 4).

$$
\begin{array}{cc}
\text { Equation 3 } & \begin{array}{c}
\text { Total moles }=0.87200-0.01915 \\
\text { AOD }\left(r=97.65 \%, r^{2}=95.37 \%\right) \\
\text { (Air) }
\end{array} \\
\text { Equation 4 } & \begin{array}{c}
\text { Total moles }=0.86448-0.00285 \\
\text { AOD }\left(r=98.71 \%, r^{2}=97.84 \%\right)
\end{array}
\end{array}
$$

(Oxygen)

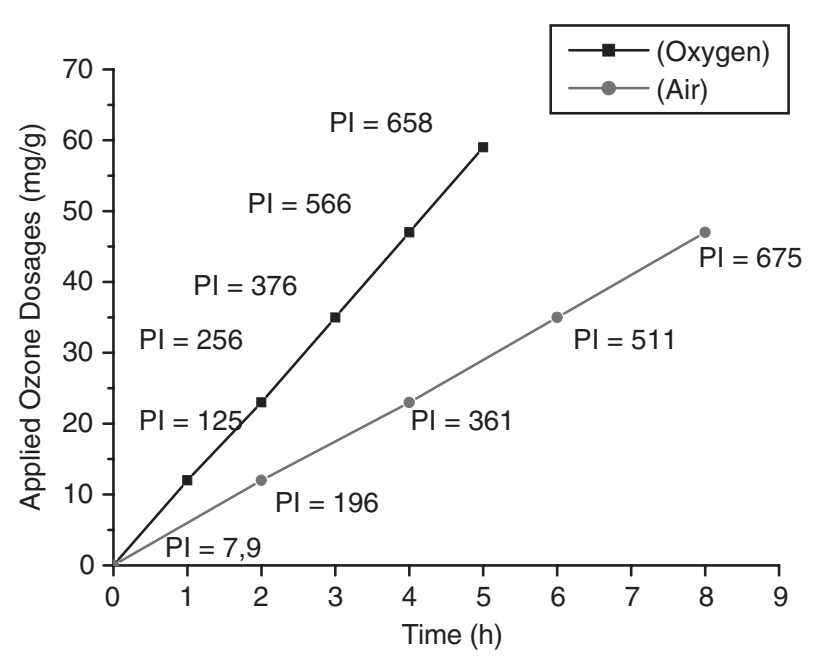

Figure 1

Lineal Correlation between Applied Ozone Doses and Reaction Time. ( $\square$ Oxygen) Ozonized sunflower oil using oxygen as ozone source; ( Air) Ozonized sunflower oil using air as ozone source; $r$ correlation coefficient; SD deviation standard; $(\square$ Oxygen) $r=99.99 \%$ SD $=0.323 ;(\diamond$ Air $) r=99.99 \%$ $\mathrm{SD}=0.316$ 
Peroxide and iodine index values along with the values for density and viscosity reported in Table 1 show linear correlations with respect to applied ozone dosages (equations 5 to 12). It can be observed that in most of the cases the better adjusted line corresponds to the ozonation reaction starting from oxygen.

$$
\begin{aligned}
& \text { Equation } 5 \quad \mathrm{PI}=20.4413+14.0914 \mathrm{AOD}
\end{aligned}
$$

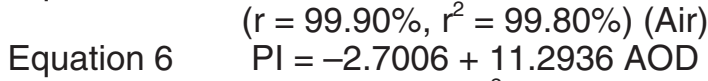

$$
\begin{aligned}
& \left(r=99.71 \%, r^{2}=99.42 \%\right) \\
& \text { (Oxygen) } \\
& \text { Equation } 7 \quad \begin{array}{l}
\mathrm{I}=120.4233+0.454 \mathrm{AOD} \\
\left(\mathrm{r}=97.84 \%, r^{2}=95.73 \%\right) \text { (A }
\end{array} \\
& \text { Equation } 8 \quad \mathrm{II}=119.4159-0.3949 \mathrm{AOD} \\
& \left(r=98.62 \%, r^{2}=97.25 \%\right) \\
& \text { (Oxygen) } \\
& \text { Equation } 9 \quad \mathrm{D}=0.9216+0.0004 \mathrm{AOD} \\
& \left(r=99.43 \%, r^{2}=98.86 \%\right) \text { (Air) } \\
& \text { Equation } 10 \quad \mathrm{D}=0.9196+0.0005 \mathrm{AOD} \\
& \left(r=99.46 \%, r^{2}=98.93 \%\right) \\
& \text { (Oxygen) } \\
& \text { Equation } 11 \quad \mathrm{~V}=32.5688+1.2492 \mathrm{AOD} \\
& \text { ( } \left.r=99.25 \%, r^{2}=98.52 \%\right) \text { (Air) } \\
& \text { Equation } 12 \quad \mathrm{~V}=34.3499+1.0847 \mathrm{AOD} \\
& \left(r=99.77 \%, r^{2}=99.53 \%\right)
\end{aligned}
$$$$
\text { (Oxygen) }
$$

As shown in Table 2, the acidity of ozonized sunflower oil starting from air as the ozone source increased 17.3-fold compared to its initial value; while the final acidity value reported in Table 1 , where the ozonized sunflower oil starting from oxygen as ozone source is reported, was only 7.3-fold higher than its initial value. This could be due to the fact that, in order to obtain an ozonized sunflower oil with a peroxide index between 600 and 700 mmol-equiv $\mathrm{kg}^{-1}$ starting from air, the ozonation reaction must be carried out over a time period of 8 hours. Nevertheless, when the same product starting from oxygen is obtained, it only requires an ozonation time of 5 hours. This increase in reaction time provokes an increase in the decomposition of peroxidic species and the oxidation of aldehydic substances into carboxylic acids within the reacting system (Criegee, 1975; Robards et al., 1988). The Linear correlation of the acidity index and applied ozone dosage is not as good as we expected, which could be due to the

\begin{tabular}{|c|c|c|c|c|c|c|c|}
\hline $\begin{array}{l}\text { AOD } \\
(\mathrm{mg} / \mathrm{g})\end{array}$ & $\begin{array}{c}\text { Time } \\
\text { (h) }\end{array}$ & Moles & $\begin{array}{c}\text { PI } \\
\left(\text { mmol-equiv } \mathbf{k g}^{-1}\right)\end{array}$ & $\begin{array}{c}\mathrm{Al} \\
\left(\mathrm{mg} \mathrm{KOH} \mathrm{g}^{-1}\right)\end{array}$ & $\begin{array}{c}\text { II } \\
\left(\mathrm{gl}_{2} 100 \mathrm{~g}^{-1}\right)\end{array}$ & $\begin{array}{c}D \\
\left(g^{-1} L^{-1}\right)\end{array}$ & $\begin{array}{c}\text { V } \\
\text { (m.Pa.s) }\end{array}$ \\
\hline 0 & 0 & 0.862 & $7.9 \pm 0.1$ & $0.12 \pm 0.002$ & $119 \pm 0.5$ & $0.921 \pm 0.0001$ & $32 \pm 0.02$ \\
\hline 12 & 1 & 0.846 & $125 \pm 3.6$ & $0.15 \pm 0.001$ & $117 \pm 1.2$ & $0.924 \pm 0.0004$ & $49 \pm 0.0$ \\
\hline 23 & 2 & 0.790 & $256 \pm 3.5$ & $0.22 \pm 0.001$ & $109 \pm 0.7$ & $0.931 \pm 0.0025$ & $60 \pm 0.02$ \\
\hline 35 & 3 & 0.753 & $376 \pm 3.3$ & $0.34 \pm 0.002$ & $104 \pm 1.1$ & $0.936 \pm 0.0002$ & $74 \pm 0.01$ \\
\hline 47 & 4 & 0.731 & $566 \pm 2.0$ & $0.60 \pm 0.004$ & $101 \pm 1.3$ & $0.944 \pm 0.0015$ & $85 \pm 0.0$ \\
\hline 59 & 5 & 0.703 & $658 \pm 2.1$ & $0.88 \pm 0.010$ & $97 \pm 0.8$ & $0.949 \pm 0.0020$ & $97 \pm 0.02$ \\
\hline
\end{tabular}
fact that carboxylic acids are not a direct product of reaction, but an indirect result of the decomposition and oxidation of the oxygenated compounds derived from the reaction. Although the relationship

\begin{tabular}{|c|c|c|c|c|c|c|c|}
\hline $\begin{array}{c}\text { AOD } \\
\left(\mathrm{mg} \mathrm{g}^{-1}\right)\end{array}$ & $\begin{array}{c}\text { Time } \\
\text { (h) }\end{array}$ & Moles & $\begin{array}{c}\text { PI } \\
\left(\text { mmol-equiv } \mathbf{k g}^{-1}\right)\end{array}$ & $\begin{array}{c}\mathrm{Al} \\
\left(\mathrm{mg} \mathrm{KOH} \mathrm{g}^{-1}\right)\end{array}$ & $\begin{array}{c}\text { II } \\
\left(\mathrm{gl}_{2} 100 \mathrm{~g}^{-1}\right)\end{array}$ & $\begin{array}{c}D \\
\left(g^{-1} L^{-1}\right)\end{array}$ & $\begin{array}{c}\text { V } \\
\text { (m.Pa.s) }\end{array}$ \\
\hline 0 & 0 & 0.862 & $7.9 \pm 0.1$ & $0.12 \pm 0.002$ & $119 \pm 0.5$ & $0.921 \pm 0.0001$ & $32 \pm 0.02$ \\
\hline 12 & 2 & 0.833 & $196 \pm 3.8$ & $0.11 \pm 0.001$ & $115 \pm 1.3$ & $0.928 \pm 0.0002$ & $50 \pm 0.001$ \\
\hline 23 & 4 & 0.811 & $361 \pm 0.8$ & $0.44 \pm 0.001$ & $112 \pm 0.8$ & $0.932 \pm 0.0001$ & $61 \pm 0.0$ \\
\hline 35 & 6 & 0.768 & $511 \pm 3.5$ & $0.96 \pm 0.001$ & $106 \pm 0.6$ & $0.936 \pm 0.0004$ & $72 \pm 0.0$ \\
\hline 47 & 8 & 0.703 & $675 \pm 2.1$ & $2.08 \pm 0.005$ & $97 \pm 1.2$ & $0.943 \pm 0.0015$ & $94 \pm 0.02$ \\
\hline
\end{tabular}
between applied ozone dosage and acidity index is not as good as the relationship among the other parameters, we can still claim that there is a linear correlation, since the correlation coefficients are superior to $91 \%$ and the determination coefficients are superior to $84 \%$ (equations 13 and 14).

$$
\begin{array}{cc}
\text { Equation 13 } & \mathrm{IA}=-0.2148+0.0409 \mathrm{AOD} \\
& \left(\mathrm{r}=91.82 \%, \mathrm{r}^{2}=84.31 \%\right) \text { (Air) } \\
\text { Equation 14 } & \mathrm{IA}=0.0086+0.0128 \mathrm{AOD} \\
& \left(\mathrm{r}=94.63 \%, \mathrm{r}^{2}=89.54 \%\right)
\end{array}
$$

(Oxygen)

Table 1

Physicochemical parameters of the ozonated sunflower oil obtained with oxygen as ozone source

AOD Applied ozone dosage, Moles of double bonds, PI Peroxide index, Al Acidity index, II lodine index, D Density, V Viscosity.

Table 2

Physicochemical parameters of the ozonated sunflower oil obtained with air as ozone source

AOD Applied ozone dosage, Moles of double bonds, PI Peroxide index, Al Acidity index, Il lodine index, D Density, V Viscosity. 


\subsection{Behavior of the unsaturated fatty acids in both systems}

The determination made for the unsaturated fatty acid content in ozonized sunflower oil (Tables 3 and 4) showed similar results for both of the ozonized sunflower oils obtained by the different procedures. During the ozonation reaction of sunflower oil, unsaturated fatty acid content was progressively decreasing and consequently peroxide index was increasing. Oleic acid as well as linoleic acid, which are the unsaturated fatty acids in the highest proportions in sunflower oil, are detected in every analyzed sample (Firestone, 1999), which shows that not all double bonds of these two acids were attacked by ozone, and remain in the reacting system as modified triglycerides and non-modified triglycerides due to the ozone reaction and can be later oxidazed by the oxygenated compounds formed (Díaz et al., 2009).

It must be pointed out that during the ozonation process a group of reactions takes place, such as polymerization, which forms polymeric peroxides which increase the viscosity of the reacting medium, as well as hydrolysis reactions of the oxygenated products obtained such as ozonides and aldehydes, which increase the acidity of the medium. This can be observed in Tables 1 and 2. Cyclation and isomerization reactions also occur by means of $1,2,3$ trioxolanes and ozonides of Criegee. This whole system forms very complex mixtures of volatile and non-volatile products which are responsible for the germicidal effects of this oil (Sechi et al., 2001; Díaz et. al., 2006).

\subsection{Determination of oxygen content by Element Analysis}

The element composition of ozonized sunflower oil varies during the ozonation reaction (Table 5). When the peroxide index increases, a linear increase in oxygen content is produced which is defined by equations 15 and 16 with an adequate correlation. The best linear adjustment corresponds to the ozonation procedure starting from air (Figure 2).

$$
\begin{array}{cc}
\text { Equation 15 } & \mathrm{CO}=9.1769+0.0097 \mathrm{IP} \\
& \left(\mathrm{r}=99.71 \%, \mathrm{r}^{2}=99.43 \%\right) \text { (Air) } \\
\text { Equation 16 } & \mathrm{CO}=9.1769+0.0071 \mathrm{IP} \\
& \left(\mathrm{r}=99.52 \%, \mathrm{r}^{2}=99.05 \%\right)
\end{array}
$$$$
\text { (Oxygen) }
$$

This increase in the oxygen content is due to an increase in the quantity of oxygenated compounds in the different samples, with the highest values being 15.57 and $13.69 \%$ whether air or oxygen is used as the as the ozone source. These values are 1.7 and 1.5-fold higher than the one obtained for unozonized sunflower oil. This result is in agreement with events reported for Criegge's mechanism (Criegee, (1975)), which describes the ozonation procedure for unsaturated compounds, where peroxidic species such as hydrogen peroxides and hydroperoxides as well as aldehydes and ozonides are formed. All of these species are responsible for increasing the oxygen content in ozonized samples. This raise in the percent of oxygen content in the ozonized sunflower oil starting from air as the ozone source is in line with

Table 3

Percentage composition of the fatty acids in ozonized sunflower oil using air as ozone source, determined by Gaseous Chromatography

\begin{tabular}{crrrrr}
\hline Composition & \multicolumn{1}{c}{$\mathbf{P I}=\mathbf{7 , 9}$} & \multicolumn{1}{c}{$\mathbf{P I}=\mathbf{1 9 6}$} & $\mathbf{P I}=\mathbf{3 6 1}$ & $\mathbf{P I}=\mathbf{5 1 1}$ & \multicolumn{1}{c}{$\mathbf{P I}=\mathbf{6 7 5}$} \\
\hline $16: 0$ & $4.40 \pm 0.08$ & $6.95 \pm 0.05$ & $7.71 \pm 0.24$ & $8.21 \pm 0.21$ & $9.52 \pm 0.24$ \\
$18: 0$ & $4.15 \pm 0.09$ & $5.91 \pm 0.10$ & $6.32 \pm 0.02$ & $7.25 \pm 0.20$ & $8.72 \pm 0.14$ \\
$18: 1$ & $28.52 \pm 0.21$ & $28.19 \pm 0.14$ & $27.63 \pm 0.08$ & $27.18 \pm 0.10$ & $26.81 \pm 0.22$ \\
$18: 2$ & $61.62 \pm 0.18$ & $57.29 \pm 0.02$ & $56.4 \pm 0.10$ & $54.99 \pm 0.16$ & $52.3 \pm 0.06$ \\
$20: 0$ & $1.30 \pm 0.20$ & $1.66 \pm 0.21$ & $1.94 \pm 0.18$ & $2.37 \pm 0.18$ & $2.65 \pm 0.10$ \\
\hline
\end{tabular}

PI Peroxide index (mmol-equiv/kg). 16:0 palmitic acid, 18:0 stearic acid, 18:1 oleic ácid, 18:2 linoleic acid, 20:0 arachidic acid.

Table 4

Percentage composition of unsaturated fatty acids in ozonized sunflower oil using oxygen as ozone source, determined by Gaseous Chromatography

\begin{tabular}{crrrrrr}
\hline Composition & $\mathbf{P I}=\mathbf{7 , 9}$ & $\mathbf{P I}=\mathbf{1 2 4}$ & $\mathbf{P I}=\mathbf{2 5 6}$ & $\mathbf{P I}=\mathbf{3 7 6}$ & $\mathbf{P I}=\mathbf{5 6 5}$ & $\mathbf{P I}=\mathbf{6 5 8}$ \\
\hline $16: 0$ & $4.40 \pm 0.08$ & $6.69 \pm 0.22$ & $6.99 \pm 0.16$ & $7.47 \pm 0.10$ & $8.86 \pm 0.08$ & $9.89 \pm 0.08$ \\
$18: 0$ & $4.15 \pm 0.09$ & $4.63 \pm 0.24$ & $5.9 \pm 0.22$ & $6.37 \pm 0.18$ & $7.74 \pm 0.10$ & $8.84 \pm 0.02$ \\
$18: 1$ & $28.52 \pm 0.21$ & $28.27 \pm 0.33$ & $27.81 \pm 0.28$ & $27.57 \pm 0.16$ & $27.12 \pm 0.12$ & $26.27 \pm 0.24$ \\
$18: 2$ & $61.62 \pm 0.18$ & $58.69 \pm 0.25$ & $57.34 \pm 0.04$ & $56.38 \pm 0.14$ & $53.82 \pm 0.14$ & $52.38 \pm 0.20$ \\
$20: 0$ & $1.30 \pm 0.20$ & $1.72 \pm 0.15$ & $1.96 \pm 0.28$ & $2.21 \pm 0.10$ & $2.46 \pm 0.12$ & $2.62 \pm 0.18$ \\
\hline
\end{tabular}

PI Peroxide index (mmol-equiv/kg). 16:0 palmitic acid, 18:0 estearic acid, 18:1 oleic ácid, 18:2 linoleic acid, 20:0 araquydic acid. 
Table 5

Element composition of unozonized and ozonized sunflower oil by both pocedures, starting either from air or oxygen as ozone source. Analyses present a precision of $0.001 \%$ for carbon, $0.01 \%$ for hydrogen and nitrogen and $0.02 \%$ for sulphure

\begin{tabular}{cccccc}
\hline \multirow{2}{*}{ P I } & \multicolumn{5}{c}{ Element Composition \% } \\
\cline { 2 - 6 } & $\mathbf{C}$ & $\mathbf{H}$ & $\mathbf{N}$ & $\mathbf{S}$ & $\mathbf{0}$ \\
\hline $7.9(\mathrm{U})$ & 77.55 & 12.22 & 0.901 & 0.206 & 9.12 \\
$361(\mathrm{~A})$ & 75.60 & 11.35 & 0.073 & 0.019 & 12.96 \\
$675(\mathrm{~A})$ & 73.18 & 11.08 & 0.134 & 0.031 & 15.57 \\
$376(\mathrm{O})$ & 75.48 & 11.97 & 0.443 & 0.009 & 12.10 \\
$658(\mathrm{O})$ & 73.92 & 11.84 & 0.408 & 0.147 & 13.69 \\
\hline
\end{tabular}

PI peroxide index mmol-equiv/kg, U Unozonized, A Air, O Oxygen, C Carbon, H Hydrogen, N Nitrogen, S Sulphure.

the increase reported in the acidity index. A reasonable explanation could be that, as this reaction takes 8 hours to occur, enough time is allowed for the decomposition reactions of the peroxidic species as well as the oxidation of aldehydes, producing an increase in the acids within the reacting system.

\subsection{Analysis of EPR spectra in both systems}

Figure 3 shows EPR spectra using a magnetic field ranging from 3225 and 3600 gauss, of unozonized sunflower oil and ozonized sunflower oils obtained from air and oxygen, respectively, and with the highest values of peroxide indexes. None of them showed signs of organic free radicals in detectable concentrations. These results show that oxygenated compounds formed as a result of the ozonation reaction of sunflower oil either from air or oxygen as ozone source, are not free radicals. This

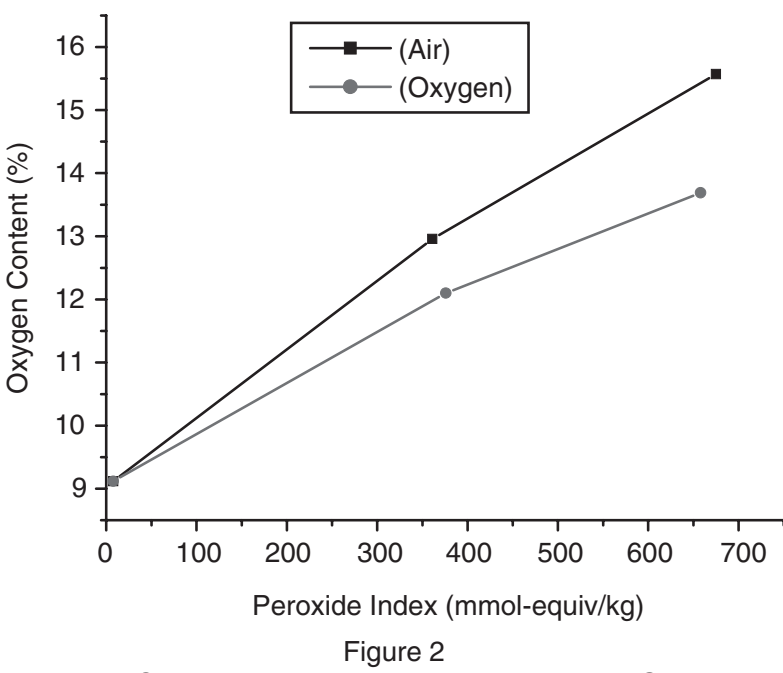

Lineal Correlation between Peroxide Index and Oxygen Content. (ם Oxygen) Ozonized sunflower oil using oxygen as ozone source; ( Air) Ozonized sunflower oil using air as ozone source; r correlation coefficient; SD deviation standard; ( Oxygen) $r=99.52 \%$ SD = 0.319; ( $\diamond$ Air) $r=99.71 \%$ $\mathrm{SD}=0.348$ leads to a remarkable result since these ozonized sunflower oils with strong germicidal effects are used as drugs and cosmetic products (Hernández et al., 2009; Díaz et al., 2010).

\subsection{Antimicrobial activity of both systems of ozonized sunflower oils}

The antimicrobial activity of ozonized sunflower oils obtained from air or oxygen as the ozone source are shown in table 6. Antimicrobial activity increased as peroxide index values increased in every studied sample. Ozonized sunflower oil obtained from oxygen exhibited the lowest values of Minimal Inhibitory Concentration (MIC) for every microorganism, except for Pseudomona aeruginosa which presented a constant value of $19 \mathrm{mg} \mathrm{mL}^{-1}$ for ozonized sunflower oils with peroxide indexes of 675 y 658 mmol-equiv $\mathrm{kg}^{-1}$, respectively. Minimal Bactericidal Concentrations (MBC) for Staphylococcus aureus did not change with both ozonized sunflower oils, however for Escherichia coli and Pseudomona aeruginosa in ozonized sunflower oil from oxygen with a peroxide index of $658 \mathrm{mmol}$-equiv/ $\mathrm{kg}$, the MBC values decreased to 89 and $178 \mathrm{mg} \mathrm{mL}^{-1}$, respectively.

Ozonized oil obtained from air as ozone source with a peroxide index value of $675 \mathrm{mmol}$-equiv $\mathrm{kg}^{-1}$ requires a higher reaction time, which leads to higher oxygen content and acidity index (Tables 2 and 5). This could be due to the fact that the decomposition of peroxidic species for the formation of acidsexplains the decrease in its microbiological activity when compared to the ozonized sunflower oil obtained from oxygen as ozone source (Table 6).

Of all microorganisms, Staphylococcus aureus was the most sensitive to both of the ozonized sunflower oils studied, with the corresponding samples containing a peroxide index of $658 \mathrm{mmol}-$ equiv $\mathrm{kg}^{-1}$ exhibiting the lowest values of MIC (4.75 $\mathrm{mg} \mathrm{mL} \mathrm{m}^{-1)}$ and with the ozonized sunflower oil obtained from oxygen being much better in the treatment of the three microorganism families. 


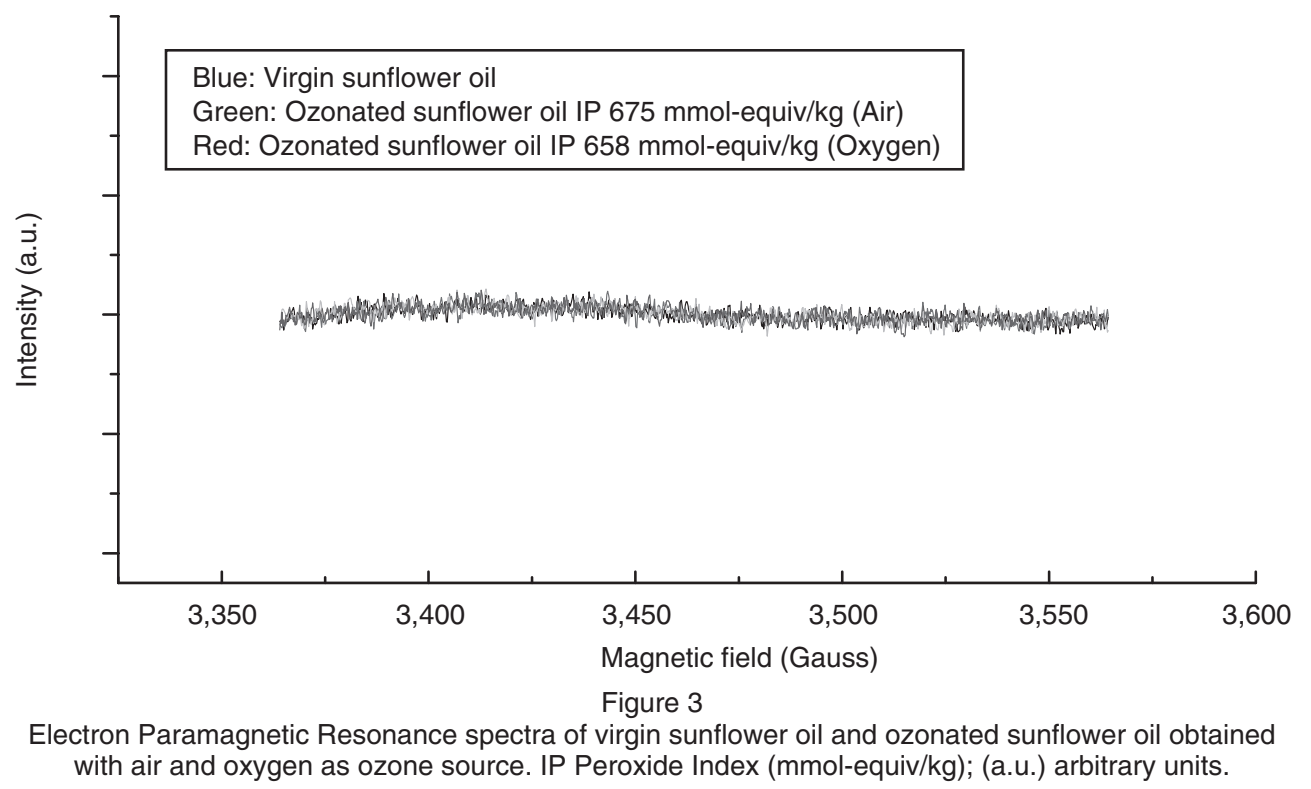

At present, knowledge about the mechanism of action of ozonized oils towards microorganisms is limited; however, it has been reported that ozonized sunflower oil (OLEOZON®), when acting on Staphylococcus aureus, decreased the protein thiol groups (SH) as one of the associated main damages because of the oxidant action of the peroxidic compounds over the cell envelope of this microorganism (Curtiellas et al., 2005). It is also claimed that the activity of ozonized sunflower oil (OLEOZON®) may be due to a toxic effect instead of the interruption of a metabolic process, just as generally occurs in the case of conventional antibiotics (Sechi et al., 2001). Other studies have proved that the antimicrobial effects of ozonized vegetable oils are due to the action of the peroxidic species on essential biomolecules of the cell, such as unsaturated lipids and proteins (Viebahn, 1993; Komanapalli et al., 1997; Chevrier et al., 1988).

Microbiological results show that ozonized sunflower oil obtained by both procedures could be used in several serious infections originated by these microorganisms, replacing conventional antibiotics.

\section{CONCLUSIONS}

It was observed that in both procedures for obtaining ozonized sunflower oil with a peroxide index between 600 and 700 mmol-equiv $\mathrm{kg}^{-1}, 0.703$ moles of double bonds were consumed in different reaction times. This parameter was equal to 5 hours when oxygen is used and 8 hours when air is used, which represents an advantage for the ozonation procedure that uses oxygen as the ozone source.

A linear relation $\left(r^{2}>99 \%\right)$ was observed when the applied ozone dosage was increased during the reaction of each one of the ozonized sunflower oils. Either with air or oxygen, there was a linear increase in the values of peroxide and iodine index, along with density, viscosity and percentage content of oxygen. This last parameter was demonstrated by the element analysis technique and therefore, this technique might be used as a different method for the quality control of ozonized sunflower oils obtained by both procedures.

An increase in the acidity index in both ozonized sunflower oils starting from air as ozone source,

Table 6

Antimicrobial Activity $(\mathrm{mg} / \mathrm{mL})$ of both ozonized sunflower oils

\begin{tabular}{|c|c|c|c|c|c|c|c|c|}
\hline \multirow[b]{3}{*}{ Microorganisms } & \multicolumn{4}{|c|}{ Ozonized Sunflower Oil (Air) } & \multicolumn{4}{|c|}{ Ozonized Sunflower Oil (Oxygen) } \\
\hline & \multicolumn{2}{|c|}{$\mathrm{PI}=361$} & \multicolumn{2}{|c|}{$\mathrm{PI}=675$} & \multicolumn{2}{|c|}{$\mathrm{PI}=376$} & \multicolumn{2}{|c|}{$\mathrm{PI}=658$} \\
\hline & MIC & $\mathrm{MBC}$ & MIC & $\mathrm{MBC}$ & MIC & $\mathrm{MBC}$ & MIC & $\mathrm{MBC}$ \\
\hline $\begin{array}{l}\text { Staphylococcus aureus } \\
\text { ATCC } 25923\end{array}$ & 19 & 178 & 9.5 & 22.5 & 9.5 & 178 & 4.75 & 22.25 \\
\hline Escherichia coli ATCC 25922 & 28.5 & 285 & 19 & 178 & 19 & 285 & 9.5 & 89 \\
\hline $\begin{array}{l}\text { Pseudomona aeruginosa } \\
\text { ATCC } 27853\end{array}$ & 28.5 & 285 & 19 & 285 & 19 & 285 & 19 & 178 \\
\hline
\end{tabular}

PI Peroxide Index (mmol-equiv/kg); MIC Minimal Inhibitory Concentration; MBC Minimal Bactericidal Concentration. 
which correlated with an increase in the percentage content of oxygen was found.In addition, this ozonized oil exhibited a higher formation of oxygenated compounds, which, by means of the decomposition of peroxides, could be related to the remarkable increase in the acidity of this oil.

It can be interpreted from the results of Electronic Paramagnetic Resonance, that oxygenated compounds formed, starting from ozonation reaction of sunflower oil either from air or oxygen as ozone source, are not free radicals. Therefore, it can be used as a germicidal product either in pharmaceutical or cosmetic industry.

The antimicrobial activity of ozonized sunflower oils obtained starting either from air or oxygen as ozone source on the microorganisms Staphylococcus aureus ATCC 6538, Escherichia coli ATCC 10536 and Pseudomona aeruginosa ATCC 27853, increased when the applied ozone dosage was raised. This effect was much higher for the ozonized sunflower oil starting from oxygen.

\section{ACKNOWLEDGMENTS}

We wish to thank CITMA-CNPq for providing financial support.

\section{REFERENCES}

Bailey P. 1978. Ozonolysis of Olefins. Academic Press, New York.

British Pharmacopeia. 2000a. Peroxide Value, Appendix XF, IA, London.

British Pharmacopoeia. 2000b. Acid value, Appendix XB, IA, IB, London.

British Pharmacopoeia. 2000c. Iodine value, Appendix XE, IA, IB, London.

British Pharmacopeia. 2000d. Determination of weight per mililitre, density, relative density and apparent density, Appendices V G, London.

British Pharmacopeia. 2000e. Determination of Viscosity, Appendix VH, London.

Chevrier N, Fathey S, Young S. 1988. Oxidative damages and repair in Euglena gracilis exposed to ozone. I. SH groups and lipids. Plant Cell Physiol. 29, 321-327.

Criegee R. 1975. Mechanism of Ozonolisis, 14 Ed. Angewandte Chemie Int, England.

Curtiellas V, Gómez M, Ledea O, Fernández I, Sánchez E. 2005. Actividad antimicrobiana del OLEOZON® sobre Staphylococcus aureus y Pseudomonas aeruginosas. Rev. CENIC Ciencias Biol 36, No. Especial.

Díaz M, Gavín JA, Ledea O, Hernández F, Alaiz M, Garcés R. 2005. Spectroscopic chracterization of ozonated sunflower oil. Ozone Sci. Eng. 27, 247253.

Díaz M, Hernández R, Martínez G, Vidal G, Gómez M, Fernández H, Garcés R. 2006. Comparative study of ozonized olive oil and ozonized sunflower oil. J .Brazil Chem. So. 17, 403-407.

Díaz M, Martínez G, Gavín JA, Meneau RI, Fernández I. 2007. Estudio de la grasa de teobroma ozonizada usando la Resonancia Magnética Nuclear protónica y análisis microbiológico. Grasas Aceites 58, 15-19.
Díaz M, Gavín JA, Andrade JB. 2008. Structural characterization by Nuclear Magnetic Resonance of ozonized triolein. Grasas Aceites 59, 274-281.

Díaz $M$, Ledea $O$, Gómez $M$, Garcés R, Alaiz $M$, Martínez-Force E. 2009. Estudio comparativo de la ozonización de aceites de girasol modificados genéticamente y sin modificar. Quim Nova 32, 24672472.

Díaz M, Meneau RI, García G, Sánchez Y, García K. 2010. Evaluación del poder irritante del jabón bactericida BELLOIL $@$ Rev CENIC Ciencias Biol, Suplemento Especial.

Firestone D. 1999. Physical and chemical characteristics of oils, fats and waxes. Ed AOCS Press, EU.

Garcés R, Mancha M. 1993. One-Step lipid extraction and fatty acid methyl esters preparation from fresh plant tissues. Anal Biochem. 211, 139-143.

Geeraert E, Shepeer D. 1982. Structure elucidation of triglycerides by chromatographic techniques. Part 1 Capillary GC of ozonized triglycerides. J. High Res. Chromatog. Commun. 5, 80-84.

Gunstone F, Haewood L, Padley B. 1994. The lipid handbook. Chapman. Hall Ed, London.

Ledea O. 2003. Estudio de la composición química del aceite de girasol ozonizado OLEOZON®. Tesis Presentada en Opción al Grado Científico de Doctor en Ciencias Químicas. Ciudad de La Habana, Cuba.

Hernández F, Hernández D, Zamora Z, Díaz M, Ancheta O, Rodríguez S, Torres D. 2009. Giardia duodenalis: Effects of an ozonized sunflower oil product (Oleozon®) on in vitro trophozoites. Exp. Parasitol 121, 208-212.

Komanapalli IR, Mudd JB, Lau HS. 1997. Effect of ozone on metabolic activities of Escherichia coli K-12. Toxicol Lett. 90, 61-66.

Lezama TR. 1997. Espectroscopia de Resonancia Paramagnética Electrónica. Servicio Editorial Euskal Herriko Unibertsitatea, Argitarapen Zerbitzua, Universidad del País Vasco.

Martínez G, Hernández R, Díaz M. 2005. Determinación de hidroperóxidos totales en aceite de girasol ozonizado mediante el método de oxidación ferrosa en xilenol naranja. Grasas Aceites 56, 147-152.

Molerio J, Menéndez S, Ledea O, Díaz M, Rubí D, Fernández A, Lezcano I. 2009. Procedimiento para la obtención de aceites y grasas vegetales ozonizados para fines farmacéuticos y cosmetológicos. CU 23467, Resolución No. 2974, La Habana.

NC norma cubana. 1998. Aceites vegetales refinados comestibles 5. Especificaciones. $1^{\text {ra }}$ Edición Oficina Nacional de Normalización.

NCCLS. 1999. National Committee for Clinical Laboratory Standards. Method for Determining Bactericidal Activity of Antimicrobial Agents. Approved guideline, 19(18).

NCCLS. 2000. National Committee for Clinical Laboratory Standards. Methods for dilution antimicrobial susceptibility, Testing of anaerobic bacteria that grow aerobically. Approved Standard, Fifth edition, 20 (2).

Pasto D, Johnson C. 1980. Determinación de estructuras orgánicas. Pueblo y Educación ED, Ciudad de la Habana.

Robards K, Kerr A, Patsalides E. 1988. Rancidity and its measurement in edible oils and snackfoods. Analyst $113,213-224$

Sánchez Y, Díaz M, Hernández F, Gil D, García G. 2011. Antioxidant effects of an ozonized teobroma oil formulation on damaged-inflammatory rat skin. Grasas Aceites 62, 105-110, 2011. 
Sechi LA, Lezcano I, Nuñez N, Espim M, Dupre I, Pinna A, Molicotti P, Zanetti S. 2001. Antibacterial activity of ozonized sunflower oil (Oleozon). J. Appl. Microbiol. 90, 279-284.

Statistic. 2003. Release, 6 Copyright Statsoft. Inc: All rights reserved.
Viebahn R. 1993. Therapeutical efficacy and toxicity of ozone induced peroxides. Proceeding of the $11^{\text {th }}$ Ozone World Congress. San Francisco. USA. 133-144.

Recibido: 30/7/12 Aceptado: 5/9/12 